\title{
Kemalism, Westernization, and Turkish Left ${ }^{*}$
}

\author{
Kemalizm, Batılılaşma ve Türk Solu
}

\author{
Doç. Dr. Erkan DOĞAN (iD) 1
}

\begin{abstract}
This article analyzes the question of how a left-Kemalist current in Turkey in the 1960s understood early Kemalist reform period, in particular, and Ottoman-Turkish modernization, in general. Leading figures of this current of thought advocated a Third Worldist, national developmentalist outlook; and Kemalism was an important key element of their understanding of socialism. They glorified the reform attempts of the early Republican era as a progressive, revolutionary transformation. They argued that Kemalist telos of reaching the level of contemporary Western civilization was in parallel with their understanding of national developmentalism. The common belief of the Turkish left in the 1960s was that an underdeveloped country could only develop by breaking all ties with the Western imperialism and adopting a development strategy composed of state ownership, heavy industrialization and central, compulsory and state-led planning. This strategy was thought to be in harmony with Kemalist vision of elevating Turkish nation to the level of Western civilization, and was seen as the only way that could elevate Turkey to a higher level of civilization. In short, in this article, a left-Kemalist account of the modernization history of the late Ottoman and the early Republican periods will be analyzed specifically by reference to the writings of Doğan Avcıŏglu and Niyazi Berkes.
\end{abstract}

Keywords: Left-Kemalism, Kemalism, westernization, developmentalism

Paper Type: Research

\section{$\ddot{O} z$}

Bu çalışmada 1960’lı yıllarda ortaya çıkmış olan sol Kemalist bir akımın, özel olarak Kemalist reform dönemini ve daha genel olarak Osmanlı ve Türkiye modernleşmesini nasıl anlamış olduğu üzerinde durulacaktır. Bu düşünce akımının önde gelen isimleri Üçüncü Dünyacı, ulusal kalkınmacı bir sosyalizm anlayışını savunmaktaydılar ve Kemalizm bu sosyalizm anlayışının oldukça önemli anahtar unsurlarından birini oluşturmaktaydı. Aynı isimler erken Cumhuriyet döneminin reform girişimlerini ilerici ve devrimci bir dönüşüm olarak övmekteydiler. Kemalist, Batılı muasır medeniyetler seviyesine ulaşma hedefiyle, kendi ulusal kalkınmacılık anlayışları arasında bir paralellik olduğunu düşünmekteydiler. Türk solunun 1960'lardaki genel inancı, azgelişmiş bir ülkenin Batı emperyalizmi ile olan bağlarını tamamen kopararak, devlet mülkiyeti, ağır sanayileşme, merkezi planlamayı içeren bir stratejiyi uygulayarak gelişebileceği yönündeydi. Bu stratejinin, Kemalizm'in Türk milletini Batı medeniyeti düzeyine ulaştırma hedefiyle uyumlu olduğu ve yalnızca bu stratejinin Türkiye'yi muasır medeniyetler seviyesine ulaştırabileceği düşünülmekteydi. Dolaysıyla, bu makalede, geç Osmanlı ve erken Cumhuriyet dönemlerinin modernleşme tarihinin sol Kemalist bir açıklaması Doğan Avcıŏlu ve Niyazi Berkes'in çalışmalarına referans verilerek ele alınmaya çalışılacaktır.

Anahtar Kelimeler: Sol Kemalizm, Kemalizm, batılılaşma, kalkınmacılık

Makale Türü: Araştırma

\footnotetext{
*This article is from the author's doctoral dissertation entitled, "Articulating Socialism with Nationalism: A Critical Analysis of Nationalism in the Turkish Leftist Tradition in the 1960s" supervised by Prof. Dr. Ümit Cizre at Bilkent University in 2010.

${ }^{1}$ Kocaeli Üniversitesi, İktisadi ve İdari Bilimler Fakültesi, Siyaset Bilimi ve Kamu Yönetimi Bölümü, erkan.dogan@kocaeli.edu.tr

Atıf için (to cite): Doğan, E. (2021). Kemalism, westernization, and Turkish left. Afyon Kocatepe Üniversitesi Sosyal Bilimler Dergisi, 23(4), 1514-1522.
} 


\section{Introduction}

A leftist interpretation of Kemalism gained a substantial ground within the ranks of Turkish left in the 1960s. In the new political atmosphere of the period following the military coup of 1960, Kemalism was re-invented by the Turkish left as a progressive, anti-imperialist, anti-feudal, and developmentalist ideology. A growing left-Kemalist current of the period, publicizing its views in the pages of a weekly journal, Yön, played a crucial role in the efforts of promoting a leftist version of Kemalism. Yön, a journal which was founded by writer-journalist Doğan Avcioğlu, was published between December 1961 and June 1967. ${ }^{2}$ During its publication, Yön became very influential among a leftist reading public and had an impact on the formation of the Turkish left of the 1960s. The Yön circle's socialism was a mixture of Kemalism and Third World socialism. In this mixture, socialism was seen as a complement of Kemalism and its principles. One important feature of the socialism which was advocated by the followers of the Yön circle was its national character. The aim of Turkish socialism was to develop Turkish nation economically and socially. The common belief of the Turkish left in the 1960s was that an underdeveloped country could only develop by breaking all ties with the Western imperialism and adopting a development strategy composed of state ownership, heavy industrialization and central, compulsory and state-led planning. This strategy was thought to be in harmony with Kemalist vision of elevating Turkish nation to the level of Western civilization, and was seen as the only way that could elevate Turkey to a higher level of civilization. The other important feature of the left-Kemalism of the 1960s was compatible with its national character. Turkish socialism was supposed to be based on a broad national coalition of different social classes and groups, the leadership of which was to be played by an alliance of progressive and Kemalist civil-military bureaucrats and intellectuals.

The Yön circle's portrayal of Kemalism was elaborated within the circle's account of the modernization history of the late-Ottoman and the Republican eras. We are provided with a specific reading of this history from the prism of the concepts of development/underdevelopment, anti-imperialism, independence, and Westernization. In the following pages, first, a left-Kemalist interpretation of the modernization history of the late Ottoman and the early Republican eras with a focus on the role of Kemalism within this history will be analyzed by reference to the writings of Doğan Avcıŏglu. Secondly, left-Kemalism's understanding of Westernism will be focused on, this time, by reference to the works of Niyazi Berkes.

\section{Westernization as Development}

Yön Bildirisi (1961), which was published in the first issue of the journal, summarizes the Yön circle's perspective on the ideas of Westernization and development. For left-Kemalism, these two concepts were associated. Attaining level of modern civilization involves "the final solution of the problem of education, the enlivening of Turkish democracy, the realization of social justice and the establishment of democratic regime." But, reaching to the level of Western civilization, the main purpose of Kemalism, can only be achieved by rapid economic development, "by approaching to the productivity level of the West." 3

This emphasis on the connection between Westernism and development can also be seen in Yön circle's account of the history of Ottoman-Turkish modernization. This history was looked at from the prism of the notion of development. The best example of such attempts was produced by the leading figure of the circle, Doğan Avcioğlu (1969), in his

\footnotetext{
${ }^{2}$ For the Yön movement, see, Atılgan (2002); Aydınoğlu (1992, pp.73-85; 107-119); Landau (1974, pp.50-64; 79-87); Lipovsky (1992, pp.85-108); Özdemir (1986); Özdemir (2000)

${ }^{3}$ Yön Bildirisi was translated into English by Tachau (1963, pp.75-78).
} 
volumes work, Türkiye'nin Düzeni. ${ }^{4}$ In Avc1oğlu's work (1969, pp.121, 223), the $19^{\text {th }}$ century history of the Ottoman Empire was presented as the era of integration and subordination of the Ottoman economy into the world capitalist system, bringing along penetration of imperialism into the country. Accordingly, this history was presented as a history of underdevelopment.

In this historical narrative, the turning point was the Free Trade Treaty signed with Britain in 1838,then with other big Western powers (see, Avcıoglu, 1969, pp.102, 104-108; Avcioğlu, 1985, pp.1065-1066). ${ }^{5}$ Reform attempts of the Tanzimat era, following these freetrade treaties, were interpreted as the examples of economic and political dependency of the Ottoman state on Western powers. Both Tanzimat reforms and free trade treaties were imposed by the encouragements of Western powers: "The 1838 Treaty prepared the conditions for free trade. The Tanzimat, on the other hand, would bring the administrative, financial and other reforms dictated by this open market arrangement created in favor of Western interests" (quoted in Gülalp, 1994, p.160; see also, Avcıŏlu, 1969, p.118). So, for him, the Tanzimat reforms served to the British interests and turned the Ottoman state into a semi-colony of Britain and other Western powers. ${ }^{6}$ The nineteenth century Ottoman state and its high-ranked bureaucrats were labeled as the puppets of the European imperialism. Tanzimat bureaucrats together with Armenian and Greek merchants of non-Muslim minorities and the Levantine population of the empire were real beneficiaries of the period; and they gained a comprador character in the course of the time (see, Avcioğlu, 1969, pp.118, 122, 193-4; Avcioğlu, 1985, pp.1065-6).

In this historical narrative, the opposition movements of the Young Ottomans and the Young Turks were praised for their opposition to Tanzimat Westernism and for their efforts to find solutions for the devastating problems facing the Ottoman state and society. But, their propositions for saving the state and finding solutions for overcoming underdevelopment of the Ottoman society were limited with the constitutional measures. Implementation of a constitutional and educational reform would be enough to save the state and liberate the society from the consequences of underdevelopment. Although well-intentioned, these proposals were lacking analysis of imperialism and were not be able to explain the real causes of the Ottoman underdevelopment. In his evaluation of Gökalp's ideas, for instance, Avcioğlu argued that Gökalp could not give a satisfactory answer to the question of how development was possible. For Avcioğlu, Gökalp just ignored the role of imperialism in the "colonization" of the Ottoman Empire. Avcioğlu (1969, pp.262-263) wrote:

How would civilization be achieved, that is to say, how would development be carried out? This task that we haven't yet accomplished for 150 years seemed very easy to him [Gökalp]. Muslim and Turkish entrepreneurs would bestir themselves, buy machinery from the West, build up roads, bridges, etc. By this way, Turkey would become civilized, and would develop... The key point was not to take the culture from Europe. Gökalp accused the Tanzimat bureaucrats of letting the Western culture in the country, but not because of transforming it into a semi-colony in the economic sense. From the viewpoint of Gökalp, Tanzimat cosmopolitanism was not the direct consequence of economic colonialism. According to Gökalp, it was possible to be protected from the Western culture in a semi-colonial Turkey. This inadequacy in evaluating imperialism... led to the belief that those goals, civilization and development, can easily be achieved.

\footnotetext{
${ }^{4}$ Türkiye'nin Düzeni: Dün-Bugün-Yarın was first published in December 1968. The book looks a like a collection of what he wrote in Yön.

${ }^{5}$ This treaty was followed by other similar commercial conventions between the Ottoman state and other European countries, which destroyed protective tariffs, state's restrictions on exports and imports, opened Ottoman markets and raw materials to foreign capital, and played an important role in the penetration of world capitalism into the Ottoman economy. See, Pamuk (1987, pp.1819).

${ }^{6}$ The process opened up by free trade treaties was accompanied by external borrowing. The foreign loans, seen as a solution for raising state revenues, graved the process of semi-colonization and increased financial dependence of the Ottoman economy on the Western imperialism. The consequence of the external borrowing was the direct economic control of the Ottoman economy and its financial enslavement by the European powers, a process which was institutionally crystallized with the establishment of Düyun- $u$ Umumiye (the Ottoman Public Debt Administration) in 1881.See, Avc1oğlu (1969, pp.126-134).
} 
It was the national liberation war of 1919-22 under the leadership of Mustafa Kemal that gave the first serious struggle in the last 150 years of the late Ottoman-Turkish history against imperialism and its internal collaborators for attaining civilization and development. According to this account, the Liberation War was waged internally against the Ottoman State, its representatives and the comprador bourgeoisie and externally against the Western imperialism. In this sense, the Kemalist Revolution, seen as the forerunner of the antiimperialist Third World revolutions of the post-colonial era, was thought to represent a radical rupture with the Ottoman Ancien Regimé through an anti-imperialist revolution. Unfortunately, this revolution, which was carried out under the leadership of petty bourgeois military-civilian bureaucracy, was left no choice but to make concessions to some conservative forces like local notables in order to secure the support of the peasantry. The Kemalist leadership was not able to deepen the revolution by more radical social and economic reforms, and the effects of the revolution was mostly felt at the superstructural level of the Turkish society. The most important inadequacy of the Kemalist Revolution was its inability to carry through a full-fledged land reform aiming at liquidating big land ownership and re-distributing confiscated land to landless peasantry. Such a land reform could have eliminated the reaction of the local notables and dramatically enlarged the new regime's support base through gaining the support and consent of the large masses of the peasantry (see, Avc1oğlu, 1969, pp.504-5).

Although unfinished and interrupted, the Kemalist Revolution was seen as the first major step on the way to true national liberation and first attempt at implementing a national development strategy based on statism. Kemalist model of statist development involved state protectionist measures (state control of foreign trade and internal market), state-led industrialization, nationalization of some critical foreign investments in the fields of public utilities, mining and railroads. ${ }^{7}$ All these efforts were complemented (and tried to be coordinated) by the First Five-Year Development Plan. Turkey, after the Soviet Russia, was the first country which adopted policy of state-led, central and compulsory planning (see, Hershlag, 1988, p.6). Through a certain reading of this model of development adopted by the new Kemalist regime, the Turkish left of the 1960s legitimized their ideology of national developmentalism.

As the Kemalist regime of the early Republican era was praised as an antiimperialist, national developmentalist revolutionary breakthrough, the years following the accession of the Democratic Party (DP) to power in 1950 were seen as the era of counterrevolutionary resurgence. The change of the government in the 1950 general elections was considered as the signal of the restoration of the Tanzimat Westernism under the DP rule. For the Turkish left of the 1960s, the DP government was representing the interests of the alliance between the Western imperialism and its domestic collaborators, i.e. the big land lords and the new comprador bourgeoisie. The DP government abandoned the policy of self-sufficiency and independent development strategy of the previous period, and integrated Turkey once again into the world capitalist system through opening Turkish economy to foreign capital (Avcioğlu, 1969, pp.515-85).

\section{Left-Kemalist Perception of Westernization}

In the political imagination of the left-Kemalism of the 1960s, as it has been argued above, the idea of social and economic development was identified with the attainment of the level of modern Western civilization. The idea of Westernization/modernization as the transformation of a traditional society into a modern and rational one was thought to be an intrinsic part of the process of social and economic development. But, on the other hand, development in an underdeveloped country could only be possible through fighting against the encroachment of Western imperialism. What was suggested was a kind of Westernization

\footnotetext{
${ }^{7}$ For the statism and economic policies of the early Republican era see, Boratav (1982, pp.165-190).
} 
without being subordinated to the West.

The questions of how Westernism should be understood, how the goal of Westernization should be reconciled with the idea of national independence were among issues that had to be tackled with the leading figures of left-Kemalism. The key figure in these debates was Niyazi Berkes. His articles in Yön journal on the idea of Westernization and its relationship with nationalism and the idea of social revolution triggered the debate among the leftist intellectuals of the period. ${ }^{8}$ Berkes, like Avcioğlu, embraced a very critical attitude towards the history of the Ottoman-Turkish Westernization and the intellectual history of Westernism in the modern Ottoman-Turkish society. Berkes especially put target on the idea of Westernism generated by the Tanzimat bureaucrats of the $19^{\text {th }}$ century. This caricaturized Tanzimat type of Westernism/Westernizer was also identified with imitation, opportunism, and inconsistencies in his writings. Sharing Avcıoğlu's account, Berkes also argued that Westernization evolved into a cosmopolitan and reactionary ideology at the hands of collaborationist Tanzimat bureaucrats, making the country a mere satellite of the Western imperialist powers. Westernization was not understood by the Tanzimat reformers as an all-encompassing economic and societal development and progress of the country, but mostly as imitations of Western ways in the form of superfluous and cosmetic innovations (Berkes, 1975, pp.178-184, 192-197, 201). Westernization could not be simply taking (or borrowing) some missing institutions or faculties from the West.

Tanzimat Westernism, according to Berkes, represented the first stage of a longer historical tradition, involving also, the Westernism of the Abdülhamid era and the Westernism of the Menderes governments. The issues of development and social progress and the goal of protecting national existence, sovereignty and independence could not be achieved through the policies of this type of Westernist tradition (Berkes, 1975, pp.222, 279-281). In opposition to this tradition, Berkes argued, there was an alternative historical legacy of the intellectualbureaucratic elite, expanding from the era of the Young Ottoman and the Young Turk oppositions to the Republican period, from the leading figures and organizations of the First and Second Constitutional periods to those of the Kemalist Revolution. For him, they deserved a real respect at least for their critical opposition to the collaborationist, superfluous Westernism of the other tradition. It was basically within the Young Ottoman, Young Turk and Kemalist tradition that the intellectual interest started to focus on the question of how the balance between Western civilization and local-national culture should be set up in order to avoid drawbacks of Westernization process. According to Berkes, this tension represented one of the main issues of the modern Ottoman-Turkish political thought and constituted a great intellectual challenge for most of the late Ottoman and Republican political and intellectual elite.

In the Second Constitutional period, Berkes wrote, there were three schools of thought differentiated in their explanation of the problems of the Turkish transformation and Westernization. These schools of thought according to Berkes, were Westernism, Islamism, and Turkism. Westernists, like Abdullah Cevdet, argued that Western civilization involved not only material achievements, but also a different mode of thinking and a new system of values: "The material achievements of Western civilization were only manifestations of Western ideas and values." So, "without adopting the cultural and intellectual foundations of the West, neither social reform, nor Westernization could occur." But, "the Westernists were, surprisingly, more concerned with the appropriation of the non-material aspects of Western civilization than with acquiring its material aspects. Individual freedom as against suppression of individual by the state or religion, reason as against the domination of custom and superstition, the application of the scientific mind as against ignorance- these were the basic differentials, and the powers enabling the West to make an impact on the East" (Berkes, 1998, p.352). Islamists, on the other

\footnotetext{
${ }^{8}$ Berkes's two books $(1964 ; 1965)$ on Westernism, nationalism, developmentalism and social revolution first appeared in Yön in the issues between no.57-69 and between no.98-108 respectively. These two books were edited again by Berkes and the new work was published in one volume and titled this time as Türk Düşününde Batı Sorunu (Berkes, 1975).
} 
hand, differed from Westernists in the issue of what to borrow from the West and what to reject. They accepted the superiority of Western civilization in sciences and techniques. Borrowing and imitating material aspects of Western civilization, in this sense, was not a big deal for them: "No Islamist, not even an ordinary citizen, paused before going to a physician trained in Western medicine, but such was the only concession made by the Islamists. The material civilization of the West was still secondary in their discussions; borrowing it continued to be viewed by them as a simple matter that did not involve cultural, social, or religious reforms" (Berkes, 1998, p.353).

Turkists' approach to the issue of Westernization (best represented in the writings of Ziya Gökalp) was in contrast with Islamist and Westernist approaches. But, Turkism also represented a "synthesis". The Turkists differ themselves from the Westernists and the Islamists, and they also "borrowed many elements from both" (Berkes, 1998, p.345). Berkes (1998, p.355) argued that "the Turkists were neither anti-West nor pro-West or, to put it another way, they were as pro-Western as any Westernist and as anti-Western as Islamist."

The Turkists agreed with the rationalist and intellectualist approach of the Westernists. But they also argued that the Westernists unfortunately did not understand what the true nature of the West was. Its true nature rested not in mind or reason or humanity, but in the fact that European civilization as an international community was composed of modern nations, each of which was differentiated from others by their own national cultures. According to Berkes (1998, p.355), the Turkists believed that "the basic reality of modern Western civilization was ... nationalism... This was because in the present world only nations were cultural realities. To join modern civilization, as the Western nations had, was, therefore, a matter of appropriating the international civilization, but not the national cultures of the Western nations". The Turkists, like Islamists, rejected the idea of imitating the West. But the Islamists missed the point that Turkish society was in a transformation changing itself from an ümmet to a millet. Berkes wrote that, according to the Turkists, "the religious ideals were weakening because the predominant contemporary type of society was the nation, not the religious community. All modern societies were ruled and motivated by national ideals... Islam would survive insofar as it became a living part of the national culture." Material elements of the Western civilization could be borrowed, but "the final aim would be to cultivate a national culture that was neither the Şeriat nor the preIslamic ethnic culture, nor the culture of the Western nations. Without the cultivation of Turkish culture, there could be no genuine reform and modernization "(Berkes, 1998, p.355).

The distinction between culture and civilization holds a central place in Gökalp's thought. Culture is the site of nationalism, and is composed of the customs and traditions of a particular nation; it "is unique and sui generis." Civilization, on the other hand, is the site of modernization. Civilization without a cultural foundation, according to this schema, eventually turns into a process of mechanical imitation (Berkes, 1981, p.23). The main question for Gökalp was "how the Turks should adopt Western civilization, and how this effort should be harmonized with the Turks' two historic traditions, i.e. their Turkish and Islamic backgrounds; or in other words, what the Turks as a nation and Islam as their religion would look like under the conditions of contemporary civilization". 9

Although pre-Kemalist heritage of those historical-intellectual figures, such as Namik Kemal, Ziya Gökalp, managed to generate a critical relationship with the idea of Westernization, their understanding of Westernism also had their own limitations and inconsistencies. Their Westernism based on the possibility of the compatibility between

\footnotetext{
${ }^{9}$ The modern origins of the strategy of adopting a synthesis, a middle road between Western civilization and domestic cultures can be extended back to the writings of Namık Kemal. In a similar vein, before Gökalp, Namık Kemal also embraced a similar strategy that only the material civilization of Europe should be taken, not its non-material aspects. Berkes argues that it is wrong to portray Namik Kemal as an unconditional Westernist. On the one hand, Kemal appealed to local sources, like Islamic tradition of thought or Ottomanism, and on the other hand, he tried to synthesize the Islamic political concepts with those of the Western political thought, like the doctrines of natural rights and the sovereignty of the people. What he tried to achieve was to reconcile the conflicting demands of Islamism, Ottomanism, and Westernism. See, Berkes (1998, pp.209-218; 1975, pp.206-216).
} 
Western civilization and local cultures (Islamic or national), and assumed a delicate balance between them. But these attempts at constructing such a balance was, as discussed in the previous pages, deprived of any understanding of imperialism, anti-imperialism or any idea of necessity for a rapid economic and social development (Berkes, 1975, pp.240-41). For Berkes, it was the Kemalist Revolution which managed to bring together the Westernist and antiWesternist (it can be read as anti-imperialist) tendencies in a very delicate balance, with the aim of developing the country along the lines of Western civilization, reaching the stage of the civilized nations without being subordinated to the Western powers. Berkes (1998, pp.464) argues that "Mustafa Kemal's drive 'towards the West in spite of the West' by methods contrary to Western liberalism was merely the logical consequence of his belief that the struggle for national liberation was between advanced nations and nations that allowed themselves to be exploited by their insistence on their medievalism. The West was not a West of simply 'modern sciences and techniques." There were different facets of the West that should be confronted with; and imperialism was one of them. An underdeveloped nation had no other choice but "to strive to make itself equal to the developed nations if it did not want to continue to be exploited by them" (Berkes, 1998, p.463).

The history of Westernization and nationalism before the Kemalist Revolution had its own paradoxes. In the pre-Kemalist era, Berkes (1975, p.258) argued, Westernism without a national awareness tended to turn into collaborationism, and nationalism without a Westernist perspective, on the other hand, into racism and reactionism. He was criticizing the Westernizers of the late Ottoman era for being economically, diplomatically and militarily dependent on the Western powers, or for underestimating or ignoring the imperialist face of the Western civilization. For Berkes, not only the Westernism, but also the nationalism of the pre-Kemalist era was characterized by some negative attributes. The search for national identity had to be complemented with a sincere effort towards an independent and national economic-social development. But, nationalism of the early $20^{\text {th }}$ century evolved into a racism (Turkism) or into reactionism in the form of religious nationalism. Neither Westernists nor nationalists were able to find a delicate balance between Westernism and nationalism, a reasonable method of reconciling them in a progressive way. They were not able to develop a strategy that would solve the problems of development and social progress, on the one hand, and that would fulfill the goal of protecting national existence, sovereignty and independence, on the other.

For Berkes, reactionism (gericilik), imperialism and underdevelopment (economic and social deprivation) were the main problems of Turkish society, hindering its progress. It was the amalgamation of an anti-imperialist and nationalist tendency and a Westernist outlook that could find solutions to these problems of the country. But, Turkish nation should jealously protect its independence during its relationship with the West; otherwise Turkish nation would not be able to avoid the imperialist pressure of the West. Turkey could keep its national independence and achieve a social and economic modernization and progress only by challenging the West (Berkes, 1975, p.186-87). But, on the other hand, Westernization and preserving national autonomy and independence were not two different irreconcilable processes, standing against each other; there was a close relationship between them, one could not be achieved without the other (Berkes, 1975, p.251). Berkes's formulation was simple: a Westernism which was deprived of a real nationalism took the form of national treason; and a nationalism deprived of Westernism took the shape of reactionism (Berkes, 1975, 187-88). The desired reconciliation was achieved through the Kemalist Revolution. The lesson that should be drawn from the success of the Kemalist Revolution, according to Berkes (1975, p.250), was the motto of 'Westernization despite the West'. Westernization should be approached neither with an admiration for, nor with an enmity toward the Western civilization.

\section{Conclusion}

One of the characteristics of the left-Kemalism (and Turkish left in general) of the 1960s was nationalism; and this can be interpreted as a way of reflecting the resentment against 
the subordination of the country to the Western imperialist powers. But this resentment was also consisting of the recognition of, if not an admiration towards, the material and spiritual achievements of the Western civilization. After all, it was the level of the Western achievements that should be caught up with. The attainment of this level could only be achieved through the secularization of all levels of social life, rapid social and economic development and social justice. But, in the age of imperialism, this aim, social and economic development and progress, could only be achieved by adhering to national independence. The success of the path of development and progress in Turkey was depending on Turkey's ability to break its ties of dependency on Western imperialism. What was needed was an independent and national strategy that would underline the distinctiveness of the Turkish context on the one hand, and elevate Turkey to the development level of contemporary civilization, on the other. The question was to reconcile the particularity of the national context, the inner domain, with the universal criterions of development and progress, the outer domain. That is to say, the issue was to build up a delicate balance between the national difference (and autonomy) and the standards of contemporary civilization (its institutions, norms and technology).

\section{References}

Atılgan, G. (2002). Kemalizm ile Marksizm arasında geleneksel aydınlar: Yön-Devrim hareketi. İstanbul: TÜSTAV.

Avcıoğlu, D. (1969). Türkiye’nin düzeni: Dün-bugün-yarın. Ankara: Bilgi Yayınevi.

Avcıoğlu, D. (1985). Mili Kurtuluş tarihi, Üçüncü kitap. İstanbul: Tekin Yayınevi.

Aydınoğlu, E. (1992). Türk solu (1960-1971): Eleştirel bir tarih denemesi, İstanbul: Belge Yayınları.

Berkes, N. (1964). İki yüzyıldır neden bocalıyoruz? İstanbul: Yön Yayınları.

Berkes, N. (1965). Batıcılık, ulusçuluk ve toplumsal devrimler. İstanbul: Yön Yayınları.

Berkes, N. (1975). Türk düşününde batı sorunu, Ankara: Bilgi Yayınevi.

Berkes, N. (1981). Turkish nationalism and Western civilization: Selected essays of Ziya Gökalp. Wesport, Conn.: Greenwood Press.

Berkes, N. (1998). The development of secularism in Turkey. London: Hurst \& Company.

Boratav, K. (1982). Türkiye'de devletçilik. Ankara: Savaş Yayınevi.

Gülalp, H. (1994). Capitalism and the modern nation-state: Rethinking the creation of the Turkish Republic. Journal of Historical Sociology, 7(2), 155-176.

Hershlag, Z. Y. (1988). The contemporary Turkish economy. London and New York: Routledge.

Landau, J. M. (1974). Radical politics in Turkey. Leiden: E.J.Brill.

Lipovsky, I. (1992). The socialist movement in Turkey 1960-1980. Leiden: E.J.Brill.

Özdemir, H. (1986). Kalkınmada bir strateji arayışı: Yön hareketi. Ankara: Bilgi Yayınevi.

Özdemir, H. (2000). Doğan Avcıoğlu: Bir Jön Türk'ün ardından. Ankara: Bilgi Yayınevi.

Pamuk, Ş. (1987). The Ottoman Empire and European capitalism, 1820-1913, Cambridge: Cambridge University Press.

Statement on economic development in Turkey. (1963). Middle Eastern Affairs, 14,(3), 7578.Yön bildirisi. (1961). Yön, 1. 


ETIKK ve BİLİMSEL İLKELER SORUMLULUK BEYANI
Bu çalışmanın tüm hazırlanma süreçlerinde etik kurallara ve bilimsel atıf
gösterme ilkelerine riayet edildiğini yazar(lar) beyan eder. Aksi bir durumun tespiti
halinde Afyon Kocatepe Üniversitesi Sosyal Bilimler Dergisi'nin hiçbir sorumluluğu
olmayıp, tüm sorumluluk makale yazarlarına aittir.

